\title{
Roadside landscaping with native plants in the Czech Republic: a review
}

\begin{abstract}
Czech Republic has a unique experience in greening the roadsides. The changes that were implemented in the early 1990s have had also been incorporated into the roadside landscape in recent years making the Czech Republic one of the forerunners in greening the roadsides. Most of the roadside landscaping designs were inspired from western landscapes comprises mostly of exotic species, which do not reconcile with the environmental conditions of the Czech Republic. The intensive use of exotic species in artificial vegetation, high water requirements for the Czech Republic greenery with water shortages are causing major environmental and ecological challenges. Fortunately, the Czech Republic hosts a unique flora and fauna that show remarkable adjustment to harsh weather conditions. Here we emphasize the use of native plants due to their potential to develop roadside landscapes in water shortage conditions, leading to reduced water usage for roadside landscaping. The preservation of native biodiversity of the Czech Republic will be an added benefit. In this article the main aspects of the Czech Republic roadside landscaping efforts, with the associated water resources using native plants in landscaping, problems in promoting native plants contrast to non-native plants in landscaping and possible solutions are discussed.
\end{abstract}

Keywords: landscaping, native plants, maintenance, exotic, Czech Republic, vascular plant flora, bryoflora, spontanea
Volume 2 Issue 3 - 2018

\author{
Mohammad Hasan Chowdhury,' Mohammad \\ Sujoun Lasker ${ }^{2}$ \\ 'Department of Food Technology and Nutrition Science, \\ Noakhali Science and Technology University, Bangladesh \\ ${ }^{2}$ Department of Geography and Environment, Jahangirnagar \\ University, Bangladesh
}

\section{Correspondence: Mohammad Hasan Chowdhury,} Department of Food Technology and Nutrition Science, Noakhali Science and Technology University, Sonapur, Noakhali-38I4, Bangladesh, Email mdhsnchowdhury@gmail.com

Received: April 02, 2018 | Published: May |4, 2018

\section{Introduction}

The Czech Republic is a small country located in the center of the European continent bordered by the countries of Austria, Slovakia, Germany, and Poland, covering an area of $78,867 \mathrm{~km}^{2}$. Since in the early 1990s, huge development programs are started to gain sustainability. As a part of this national development in Czech Republic enormous resources are utilized for urban landscaping and agricultural development. In the past 20 years not only it has changed incredibly by cutting down on greenhouse gas production and use of natural resources that are very harmful to the environment, but also integrated programs that will help protect the magnificent landscape of the Czech Republic. ${ }^{2}$ The Czech Republic has implemented greenery policies on the roadsides as a part of huge development plan that has taken into account in the early 1990s. This artificial construction of a green nature has been cause of many environmental issues also.

\section{Urban roadside landscape developments in Czech Republic}

Over a short period of time, by planting both native \& non-native plants, roadsides in the Czech Republic have been transformed into green lands. Greening roadsides of the Czech Republic is actually an active material construction of a nature. Moreover, urban roadside landscaping of Czech Republic appears difficult to reconcile with the ecological, social and cultural conditions of the country.

\section{Threats to Czech Republic biodiversity}

The roadside trees have been steadily shrinking in the Czech Republic in last few years \& causing threats to Czech Republic biodiversity. The impact of this erosion in plant biodiversity has created environmental and socioeconomic problems which subsequently triggered the need of conservation of plant resources.

Arnika $^{3}$ environmentalist group opposed to the point of some experts who says that roadside trees pose a danger to drivers and can be a cause of accidents and should be removed from along roads or their selected sections at least. According to Arnika, ${ }^{3}$ the accidents are not to blame on tree alleys but on drivers' conduct. "Over 217,000 trees have disappeared from a long road since 2003, when the monitoring started, but have been replaced with about 130,000 only. The situation might change to the better from now on. The government has approved a plan of the country's adaptation to climate change, which directly requires systematic planting [of trees] along roads," Arnika ${ }^{3}$ wrote. ${ }^{3}$ The government of Czech Republic made mandatory the preservation of any existing landscape plantation adjacent to proposed roadway projects. Road improvements including utility locations shall be designed to minimize removal of vegetation including the maintaining of standing trees wherever possible while, designing around them where necessary. The consultants design shall avoid, wherever possible, those habitat areas that support rare, threatened or endangered wildlife species. Republic government continues its efforts in conservation of biodiversity and the protection of endangered plant species in the Czech Republic in order to promote environmental sustainability.

\section{Exotic species for roadside landscaping}

Most of the urban roadside landscapes are inspired by western landscape designs primarily focusing on aesthetics. This artificial greenery has introduced many new species in the country. Greening roadsides of Czech Republic depends mostly on imported exotic species. According to Sera $\mathrm{B}^{4}$ roadside landscapes at Czech Republic comprised primarily of non-native species. Non-native plant species need high maintenance and need substantial support systems to keep 
them alive. Moreover, these exotic plants are mostly introduced from the temperate and semi-temperate regions to the arid environment of Czech Republic and have high irrigation requirements. The purpose of planting exotic species is to produce more aesthetic and green environment on roadsides. The exotic species may become invasive and become environmental risk. Due to this reason we have to focus the indigenous plants while selecting plants for our roadside landscapes. Native plants have capacity to adapt the hostile arid environmental conditions which is an important factor to select them for landscaping. As native plants are adapted to the local environment they have advantage over exotics plants that they are less likely to become invasive. ${ }^{5,6}$ The non-native or exotic woody species that have been determined along the roads in Czech Republic are Acer negundo, Ailanthus altissimus, Amorpha fruticosa, Robinia pseudoacacia, Symphoricarpos albus, etc. These introduced species consume huge quantity of sweet water, mainly from groundwater water source. Roadside landscapes of Czech Republic now comprises of following exotic species. $^{7}$

Acer negundo (Sapindaceae), Amaranthus powellii (Amaranthaceae), Amaranthus retroflexus (Amaranthaceae), Asclepias syriaca (Apocynaceae), Bassia scoparia (Amaranthaceae), Bidens frondosus (Asteraceae), Bunias orientalis (Brassicaceae), Cannabis sativa var. spontanea (Cannabaceae), Conyza canadensis (Asteraceae), Cuscuta campestris (Cuscutaceae), Echinops sphaerocephalus (Asteraceae), Erigeron annuus (Asteraceae), Galinsoga parviflora (Asteraceae), Helianthus tuberosus (Asteraceae), Heracleum mantegazzianum (Apiaceae), Impatiens glandulifera (Balsaminaceae), Lupinus polyphyllus (Fabaceae), Oxalis corniculata (Oxalidaceae), Oxalis dillenii (Oxalidaceae), Prunus serotina (Rosaceae), Reynoutria japonica var. japonica and R. sachalinensis (Polygonaceae), Rudbeckia laciniata (Asteraceae), Rumex longifolius subsp. sourekii (Polygonaceae), Sisymbrium loeselii (Brassicaceae), Solidago canadensis (Asteraceae), Solidago gigantea (Asteraceae), Symphoricarpos albus (Caprifoliaceae), Telekia speciosa (Asteraceae).

\section{Water status \& requirements for roadside landscaping}

The Czech Republic has the highest consumption of water per capita in Europe, with the domestic consumption of 41 per cent, industrial consumption of 57 per cent $\&$ only 2 per cent of water is utilized for different greening projects. ${ }^{8}$ Czech Republic has limited fresh water resources with average annual rainfall ranges from 50 to 76 centimeters (20 to 30inches) in low-lying areas to over 127 centimeters (50inches) in the Krkonoše Mountains.

On an average, the reliable sources of surface water amount to $4796 \mathrm{millionm}^{3} /$ year while the exploitable groundwater sources can give $1339 \mathrm{~m}^{3} /$ year. After the increase of prices and the restructuring of industrial and agricultural production between 1990 and 1997 there was a significant decrease of water consumption. The specific water consumption of households is now by about $10 \%$ below, the average of EU. The sectorial breakdown of water consumption in 1997 is given in Table 1. It follows from it that the water consumption in agriculture (including irrigation) only represents about $1 \%$ of the total water consumption. ${ }^{9}$ In the Czech Republic; roadside landscaping sector will face challenges, in terms of irrigation resources. In the Czech Republic, the potential concern related to roadside landscaping is that water requirement is increasing while the groundwater supply is vanishing. The difference between the (incoming) feeding and the (outgoing) consumption of water from the aquifer has resulted in certain issues like, dryness of wells, reduction in ground water recharge.

Table I Czech Committee of the International Commission on Irrigation and Drainage given sectorial breakdown of water consumption in the Czech Republic in 1997

\begin{tabular}{|c|c|c|c|c|}
\hline Sector & $\begin{array}{l}\text { Surface water } \\
\text { consumption }\end{array}$ & & $\begin{array}{l}\text { Groundwater } \\
\text { consumption }\end{array}$ & \\
\hline & thousand $\mathrm{m}^{3}$ & $\%$ & thousand $\mathrm{m}^{3}$ & $\%$ \\
\hline $\begin{array}{l}\text { Public water } \\
\text { supplies }\end{array}$ & 500860.9 & 26.3 & 414609.3 & 88.9 \\
\hline Power plants & 854361.8 & 44.8 & 1742.7 & 0.4 \\
\hline Industry & 532103.3 & 27.9 & 38168.8 & 8.2 \\
\hline Agriculture & 13548.6 & 0.7 & 5920.8 & 1.2 \\
\hline Other & 5189.7 & 0.3 & 6035.0 & 1.3 \\
\hline Total & I 906064.3 & 100 & 466476.6 & 100 \\
\hline
\end{tabular}

\section{Impact of climate change in Czech Republic}

The Czech Republic has made tremendous leaps in terms of the sustainability used in the country. Not only has it changed incredibly in the past 20 years by cutting down on greenhouse gas production and use of natural resources that are very harmful to the environment, but it has also integrated programs that will help protect the magnificent landscape of the Czech Republic. ${ }^{2}$

Czech Republic emissions intensity, (the level of emissions per unit of economic output) is one of the highest among the mostly richcountry group of the Organization for Economic Co-operation \& Development. ${ }^{10}$ Czech Republic has started to face the climate change effects in form of extreme weather events and higher temperatures etc. In the Czech Republic such climate change poses great threat to the whole ecology. It is predicted that increase water shortage and decreased agriculture production will affect the tourism thereby revenue source also. Now Czech Republic is determined to take necessary measures to go green and sustainable.

\section{Climate change impacts on water status}

Climate change effects on temperature and rainfall can increase water shortage problem of the country. The potential changes to the climate are the cause for a very serious concern to encourage the best planning. The predicted increase in temperature will increase evaporation in the region. Due to this rise in temperature and changes in rainfall the demand for water is going to rise even more.

\section{Microclimate}

The climate is the average weather over several years divided into main zones with similar characteristics. Within a particular region, climate can differ from place to place within a few kilometers distance, forming a small scale pattern of climate, and called microclimate. ${ }^{11}$

\section{Microclimate modification}

Roadside vegetation has a strong relationship with the microclimate. Plants color and surface characteristic act as a neutralizer to the thermal environment. Decrease of air, temperature has been observed during hot summer days in areas with greenery. ${ }^{12}$ Air temperature along with greenery is considered to be the most crucial parameter in improving 
the microclimate due to its multiple benefits. ${ }^{13}$ Spangenberg et al. ${ }^{14}$ observed a small decrease in temperature for tree-aligned streets $\left(1^{\circ} \mathrm{C}\right)$, but up to $20^{\circ} \mathrm{C}$ lower surface temperatures and more than $4^{\circ} \mathrm{C}$ lower mean radiant temperatures.

It can be easily concluded that the higher the ratio of green to build area the greater the air temperature decrease is likely to be in the area. ${ }^{12}$ Studies said that the effects of roadside vegetation help reduce effects of urban heat island in Czech Republic. Application of trees having a mix of different vegetation types around the roadside is found to be the most effective strategy in tackling excess heat in urban areas. Roadside vegetation has an adverse benefit not only on the reduction of temperatures around the urban area but from many of the studies, additional benefits are received for user's comforts when traveling around or nearby vegetation.

\section{Sustainable roadside landscape}

Sustainable roadside landscaping in general the theory comprises all the environmental, social and economic elements. Sustainable roadside landscape terms as a healthy and strong landscape that is in harmony with native environmental settings containing climate, water, soil and topography. Urban roadside landscapes can significantly improve urban ecological footprint with proper design, careful energy use and plant and material selections. Advocated practices include selecting sites to maximize wildlife habitat preservation and managing storm water on site, preserving and restoring native plant communities. Different studies illustrated the significance of roadside greenery in reducing surplus heat and creating balanced microclimatic conditions in urban areas of Czech Republic. It is recommended that while designing the roadside landscape we should try to mesh with the existing surroundings, linking back to the road area's historic characteristics for additional visual benefits. Cost of maintenance of roadside vegetation in different forms and reduction in air temperature should be explored. Effects of orientation of roadside vegetation should also be analyzed.

\section{Plant selection for roadside landscaping in drought conditions}

As there is no saline soils in the country, presently strategies are adopted for sustainable roadside landscaping under adverse drought conditions; engineering the environment by irrigation and drainage management to reduce water loses or by engineering the plants to increase their drought tolerance. Most of the possible solutions are much expensive in term of money, energy and time duration. So long term effective method is the utilizing drought tolerant plant species which can be most feasible and economic solution. Complex mechanisms of a biotic stress resistance in plants make difficult to produce stress tolerant varieties. ${ }^{15}$ Plant species should also be screened under localized conditions as in most cases different response is expected. The best way to utilize the degraded land is to domesticate the wild native species rather than to increase the drought tolerance of plant species. One of the successful approach is to select the wild species that have genetic tolerance to drought stress and have some economic and landscape potential.

\section{Native plants in roadside landscaping}

There is no universally accepted definition of native plants. The U.S. fish and wildlife service defines native as "with respect to a particular ecosystem, a species that, other than as a result of introduction, historically occurred or currently occurs in that ecosystem", ${ }^{16}$ whereas, the U.S. national park service defined native plants as "all species that have occurred or now occur as a result of natural processes on lands designated as units of the national park system. Native species in a place are evolving in concert with each other". ${ }^{17}$ Regardless of the variation in terminology, generally native plants usually include plants that are found to occur in distinct natural places without the aid of, or introduction by humans. Naturally, native plants species that have grown accustomed to local climate conditions are the best when designing xeriscape, as they are enabled with high efficiency of water consumption and minimization of maintenance time and cost.

Different roadside landscape plant species are mostly considered as drought tolerant based upon anecdotal observations and performance in roadside landscape. During plant selection for a specific sites indigenous species are mostly preferred as drought tolerant by the public. ${ }^{18,19}$ Roadside landscape designs with the maximum use of native or drought tolerant species which require minimal supplemental irrigation after establishment has the potential to outclass the exotic species in roadside landscape. However, species performance is unknown in maintained roadside landscapes. It is also well known that some wild species are more salt tolerant than their cultivated relative's. Scheiber et al., ${ }^{20}$ also emphasized on the importance of selecting plant material already adapted to environmental conditions of a landscape. Native plants also assist to restore wild life habitat by providing food, shelter and other ecological parameter and increase the overall biodiversity of a given landscape. ${ }^{5,6}$ Native plants also found to attract and retain greater numbers of natural enemies and are used as habitat management in Biological control., $5,21,22$

By promoting native plants landscape architects have not only created a vernacular roadside landscape, but also helped to find solutions to rising summer temperatures and excessive use of borrowed water. Native species are also found to be better suited to difficult or unique site conditions. ${ }^{23}$ Roadside landscaping with native and indigenous plants due to their water use efficiency and all other associated ecological, cultural and landscape benefits getting importance since last few decades. Native pants are always well adapted to soil climate and environment need less maintenance less use of pesticide and fertilizer.

Usually introduced ornamental plants are difficult to acclimatize, need care and utilize enormous quantities of irrigation water in addition to other production inputs. Contrary native plants are best adapted to local climatic and soil conditions, use of native plants in roadside landscape projects can be highly beneficial in conserving limited resources. Natural roadside landscaping is an opportunity to reestablish and diverse native ecosystem while at the same time provides a natural look to roadsides reflecting the national heritage and culture. As water scarcity problem has reached at alarming level, trend is shifting towards water efficient roadside landscaping. Therefore, use of drought tolerant native plants is getting more attention. ${ }^{24}$

\section{Functional benefits associated with native plants}

Native plants of Czech Republic have been used in traditional medicine long ago in the Czech Republic but ethnobotanical literature about most of species is rare. Indigenous rangeland grasses are also important sources of feed for grazing cow and goat. These grasses survive with very little water and have excellent adaption to the harsh environment, which make them ideal choices for sustainable forage production, thus reducing the use of scarce fresh water resources. 
Native plants can help restoring wild life habitat by providing food, shelter and other ecological processes. Indigenous plants may increase native biodiversity when used to restore degraded habitats. ${ }^{6}$ For restoration and preservation purpose, native plants are of vital importance in dealing with the impacts of noxious weeds. Native shrubs and trees have critical importance in the roadsides as they provide shade shelter and habitat for indigenous wildlife. They also have an important cultural association and are aesthetically pleasing in the roadside landscape.

\section{Native plants in Czech Republic roadside landscapes}

It is assumed that common people think indigenous plant look shaggy and weedy, ${ }^{25-27}$ which don't seems true in case of Czech Republic. Native plant species including Linden (Czech Republic National tree), Norway maple (Acer platanoides), Sessile oak (Quercus robur), and many other native species are commonly found in lawns of Czech Republic national's houses which showed the interest of Czech Republic people in native plants and also proves the suitability of these plant species in all landscape. To create a sustainable city that promotes comfortable and sustainable transport routes, roadside landscaping projects are need to be implemented $\&$ completed by introducing the native plants on large scale. The soft roadside landscape design takes advantage of the native flora, by encouraging the use of native plant species, to reduce water consumption and economize maintenance costs. Adopting the policy of cultivation of native plants that are tolerant to dry conditions to beautify Czech Republic has preserved native plants species that are disappearing due to urbanization. Most of native plants are not only xerophytic in nature but also belong to halophytes which can tolerate high level of salinity. Native plants in the Czech Republic are thought to be a possible biotic solution for water shortage and sustain the roadside landscaping beauty. Indigenous plants are only way to save the future of the green sector in the country.

\section{Native plants of Czech Republic}

Fortunately sufficient scientific literature is available on the native plants of Czech Republic because Czech Republic has a long tradition of botanical research. More than two centuries of systematic studies on its flora and almost a century of vegetation research have resulted in a wealth of detailed botanical information. This country is perhaps the only one in the world for which detailed multivolume monographs of both of its flora (the last, ninth volume is under preparation) and vegetation (in four volumes) have recently been published. There are also large databases of records of plant distribution and vegetation plots, which are frequently used in basic and applied research. ${ }^{7}$

On the occasion of the centenary of the Czech Botanical Society in 2012, the society published a special issue of its journal Preslia that contained new checklists and Red Lists of the vascular plant flora and bryoflora of this country ${ }^{28-30}$ and review articles dealing with the history of botanical research, ${ }^{31}$ general information about vegetation, ${ }^{32}$ flora $^{33}$ plant invasions ${ }^{34}$ and basic overviews of bryoflora ${ }^{29}$ and lichen biota. $^{35}$

The latest statistics on the Czech flora includes 148 families of vascular plants, 925 genera, 3754 species and subspecies and 618 hybrids. Considering all the taxa ever recorded in the national flora, i.e. including native species \& subspecies and extinct natives and hybrid natives, gives totals of 2945 native taxa and indicates that make up $66.9 \%$ (Figure 1$)^{7}$
Czech Republic has habitats which host native species that show unique physiological, behavioral and morphological features to survive under harsh environmental conditions. These features have enabled these species found in the Czech Republic ecosystems to cope with summer and winter temperatures. Summer and winter temperatures are positively correlated and so is summer and winter precipitation. Both temperature and precipitation peak in July. Lowlands are warm and dry, with a mean annual temperature of $8-9.5^{\circ} \mathrm{C}$ (January mean -2 to $0^{\circ} \mathrm{C}$, July mean $18-20^{\circ} \mathrm{C}$ ) and annual precipitation of $400-600 \mathrm{~mm}$. In contrast, the highest areas in the mountains have a mean annual temperature of about $1-2^{\circ} \mathrm{C}$ (January mean about -7 to $-6^{\circ} \mathrm{C}$, July mean about $8-10^{\circ} \mathrm{C}$ ) and annual precipitation of $1200-1400 \mathrm{~mm} \cdot{ }^{37}$

Current knowledge about native plants of roadside landscapes in Czech Republic is at primary stages which cause impairment in promoting native plants in roadside landscaping for sustainable greenery, there is a great need to perform more research on this subject. Unfortunately, there is no clear list for total native and indigenous plant species and recommended species for roadside landscaping, which is the great obstacle in promoting the flora of Czech Republic flora for roadside landscaping. Therefore, more efforts have to be done, to establish a database of available recommended flora for roadside landscaping, in order to gain sustainability.

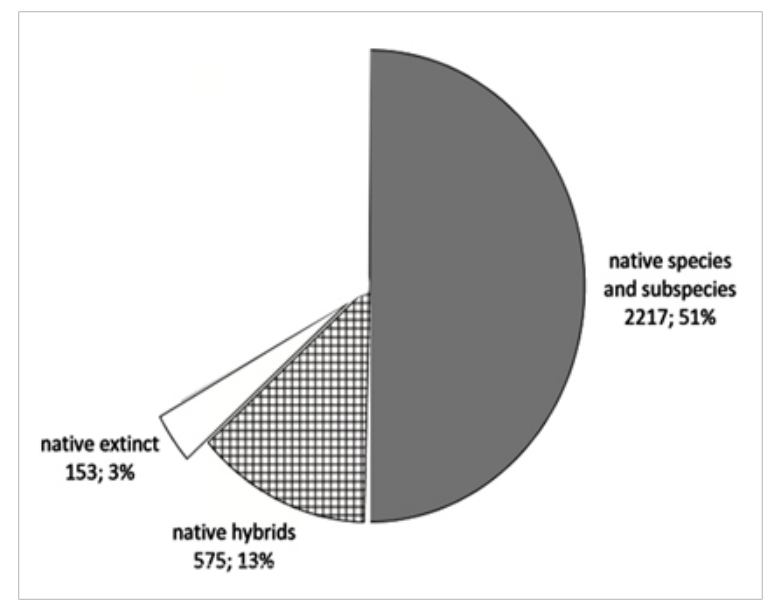

Figure I Composition of the flora of the Czech Republic in terms of its native, categories of natives, and historical and current presence of tax in this country (data on the numbers in the native flora are from Kaplan ${ }^{33}$ \& Danihelka J et al. ${ }^{28}$ )

\section{Species suitable for roadside landscape}

During the recent years a strong drive has been raised for intensive use of native plants in the roadside landscaping. Municipal authorities are focusing more on water conservation roadside landscapes in all govt. projects. Hence now roadside landscaping with native plants can be observed in all major road sides and median strip in Czech Republic. Data regarding total projects completed dominated with native plants and their impact on water conservation in city roadside landscape projects is yet to be evaluated.

Czech Republic flora is rarely studied but roadside landscape experts used traditional knowledge of Czech Republic nationals to select plants to use them for roadside landscape projects. Studies are also done in other countries in Europe with similar arid conditions and flora which can be useful. Despite the harsh environmental conditions, Czech Republic have diverse flora having which can be used for all 
requirements of any roadside landscape.

Examples of few species which can be selected for different roadside landscape needs are below

\section{Shade trees}

Abies alba, Acer platanoides, Acer campestre, Acer pseudoplatanus, Alnus glutinosa, Alnus incana, Betula pubescens subsp. Pubescens, Betula pendula, Carpinus betulus, Carpinus betulus, Fagus sylvatica, Fraxinus excelsior, Populus nigra, Populus alba, Larix decidua, Picea abies, Picea pungens, Pinus uncinata subsp. Uliginosa, Pinus strobus, Pinus sylvestris, Quercus petraea, Quercus rubra, Quercus pubescens, Quercus cerris, Salix alba, Salix caprea, Tilia platyphyllos, Tilia cordata, Taxus baccata, Ulmus glabra, Ulmus laevis, Ulmus minor.

\section{Hedges \\ Lycium barbarum}

\section{Shrubs}

Rubus idaeus, Vaccinium myrtillus, Prunus spinosa, Crataegus spp., Betula nana, Alnus alnobetul, Vaccinium myrtillus, Vaccinium vitis-idaea, Calluna vulgaris, Empetrum hermaphroditum, Empetrum nigrum, Rhododendron tomentosum, Vaccinium uliginosum, Calluna vulgaris, Erica carnea, Rubus idaeus.

\section{Grasses}

Agrostis capillaries, Bromus sterilis, Bromus tectorum, Crypsis aculeate, Crypsis schoenoides, Calamagrostion villosae, Calamagrostion arundinaceae, Calamagrostis arundinacea, Calamagrostis epigejos, Festuca rubra, Hordeum murinum, Helictotrichon desertorum, Stipa glabrata, Trisetum flavescens, Sesleria caerulea.

\section{Ground covers} minor.

Ajuja reptans, Asarum europaeum, Glechoma hederacea, Vinca

\section{The impact of roads salting on roadside landscapes}

An important part of the influence of traffic on roadside landscaping is the indirect impact of operating and maintaining the roads. In Central Europe, this mainly means salting the roads in winter. Massive use of chemicals (unlike inert spreads) has a negative impact on woods and causes changes in the natural vegetative composition of the road verges. The species sensitive to salt disappear and the more tolerant ones survive. Due to that, the halophytic species propagate in Europe: Puccinellia distans (Weeping Alkaligrass), Spergularia maritima (Media Sandspurry), Plantago maritima (Seaside Plantain), and Cochlearia danica (Danish Scurvey grass). ${ }^{38,39}$ About twenty salttolerant species have been recorded on localities along the roads in the Czech Republic (e.g. Puccinellia distans, Digitaria sanguinalis, Spergularia rubra, etc.). It is a smaller number than in seaside European countries (e.g. in Poland see Wróbel et al. ${ }^{40}$ ). Digitaria sanguinalis is an invasive plant. ${ }^{41}$ The most important halophytic species of roads is Puccinellia distans, which was found along all road classes. Puccinellia forms single-species lines of $0.25-0.35 \mathrm{~m}$ width along the asphalt edges and in the divider strips. ${ }^{40,42}$
Road nets are anthropological component in the open landscape, which bring many negative impacts to surrounding nature. Roadside landscapes are responsible for the incorporation and reduction of the negative influences of the traffic. Spreading the weeds and non-native plants along the roads as corridors into the local ecosystems represents a great problem for the natural communities. Roads and highways can encourage the entry of such plant species in four styles:

i) Road construction and maintenance (soil movement, mowing, salting, etc.) may have supportive influence on many weeds and some invasive plants.

ii) Roadsides are often planted with non-native, exotic, or invasive woody plant.

iii) Road is a corridor facilitating the spread of invasive plants.

iv) Landscape fragmentation by road net reduces the quality of natural habitat and facilitates the spreading of weeds, exotic and invasive plants into natural communities. ${ }^{43}$

\section{Promotion of native plants market}

Several reports have been published about trends in native plant markets, customer preference and problems faced by native plants growers and landscape architects. Top concerns included: Propagation, issues of genetic variability, maintenance in landscapes and on restoration sites, cultural and other information, availability of retail quality native plant material, lack of commercially available seeds, and finally, public perceptions that often hinder acceptance of projects that incorporate native plants. ${ }^{44}$ Major concerns limiting the Florida native wildflowers market included lack of shared knowledge, concerns about plant material origin and source and seed processing issues and limited seed supply. ${ }^{45}$ Most of the native plants growers face much difficulty in seed conditioning, breaking dormancy, testing seed viability, and maintaining seed viability ${ }^{44}$ Most of the native plants grower collect the seed/plants from wild, ${ }^{46}$ which can be threat to wild populations and habitats especially in case of rare plants species. Lack of scientific research on propagation techniques is a limiting factor for involvement of nurserymen and other green industry professional in more difficult to propagate species so specific propagation guidelines would be extremely valuable for nurseries and other green industry professionals. ${ }^{44}$ For landscape architect non-availability of plants, undefined maintenance requirements and difficulty in selection of plants for a site are the major constraints faced and that may inhibit the use of native plants. ${ }^{47}$ Important factors which limit the use of native plants is desired plant species and plant vigor, followed by customers' perceptions of native plant aesthetics. Customer's unfamiliarity with native plant care and limited knowledge about specific native plant use is also the matters of concern. ${ }^{48,49}$ Although promotion and adoption of native plant has been slow, customers are willing to buy and plant native species. ${ }^{50,51}$ Demand can be increased much more by educating consumer's nurserymen and landscape designers about native plants. For successful implementation and promotion of native wildflowers and native plant market, education of both professionals and the customers is critical. In addition Woosaree, ${ }^{52}$ Meyer $^{53}$ and Peppin et al ${ }^{54}$ suggested that educating consumers regarding the use of native plants would bring awareness to the native plant market. Studies should be carried out to develop viable and faster propagation methodologies of native plants. The potential of native plants to be used in landscaping due to their growth habits and their water use 
efficiency as compared to exotic species and its effect on water sources and ecology is still need to be assessed. All the available landscape plants should be evaluated for their physiological, morphological and horticultural properties to make best use of this hidden natural treasure. To ensure sustainable landscaping we need to identify stress tolerant plants with distinct morphological characters suitable for roadside landscaping. Most of the native plants recommendation seems to be based on anecdotal observations as many of them are not available in the market. Regeneration of native species is not well known and propagation techniques for most of native species are not developed and only few are available in the local market, so recommending native plants in the landscapes without proper production technology may exploit the population in the natural habitat.So before going to commercial plantation, research should be carried out to recommend best suitable technique for the commercial production and recommendation should be made based on that Educational programs should be started to increase the awareness in the public about native plants and provide technical and scientific information to landscape architects and contractors through nursery catalogs, plant lists etc. This can assist in the selection of suitable plants for landscape designs. Market surveys should be carried out to know the issues and problems faced by the nursery owners, native plants growers and landscape architects regarding native plants.

\section{Conclusion}

Roadside landscaping with native plants can be the alternative way for sustainable greenery under extreme conditions with low water with many other ecological and economic benefits. But greening roadside in Czech Republic depends completely on exotic species and irrigation water mostly from nonrenewable ground resources. Excessive use of water for irrigation and increasing population demand can be the reasons of extreme water shortage in Czech Republic in the near future. This water shortage is the limiting factor for the roadside landscaping. Native plants have different qualities due to which they can be used as fodder, medicine, landscaping, afforestation, sand stabilization, wind break and alternative crops in drought and saline conditions, all of which can contribute to sustainable greenery and maintaining specific unique and traditional roadside landscape of Czech Republic. Using native plants will not only reduce water requirement but also the maintenance, fertilizer and pesticide cost of any landscape project. Moreover landscaping with native plants will also conserve the Indigenous flora through utilization. More studies should be carried out to identify best suitable local plants and techniques for their commercial production and recommendation should be made based on that. Educational programs should be started to increase the awareness among the public about native plants and provide info to Roadside Landscape architects and contractors through nursery catalogs, plant lists etc. to help them select suitable plants for their roadside landscape designs. Through this we can improve our roadside landscape plans with maximum utilization of native species so it is more suitable in roadsides and also represent horticultural heritage of Czech Republic. We can make future designs more sustainable and traditional giving a specific identification of national landscape.

\section{Acknowledgements}

None.

\section{Conflict of interest}

Authors declare that there is no conflict of interest.

\section{References}

1. Central Intelligence Agency (CIA). The World Factbook. Czech Republic. 2010.

2. Noble S. Czech republic - sustainable horticulture and agriculture crop production. Digital Conservancy. 2010.

3. Arnika. NGO: Thousands of trees yearly disappear along Czech roads. Prague Monitor. 2017.

4. Šerá B. Vegetation bands around roads in the Czech Republic. 6th ISA European Conference MECC Maastricht. 2004.

5. Fiedler AK. Evaluation of Michigan Native Plants to Provide Resources for Natural Enemy Arthropods. Pro Quest. 2006.

6. Stephens CJ, Schellhorn NA, Wood GM, et al. Parasitic wasp assemblages associated with native and weedy plant species in an agricultural landscape. Aust J Entomol. 2006;45(2):176-184.

7. Chytrý M, Danihelka J, Kaplan Z. Flora and Vegetation of the Czech Republic. 14th ed. Springer International Publishing AG; 2017.

8. List of countries by freshwater withdrawal. In Wikipedia. 2008.

9. CZNC-ICID. Czech Committee of the International Commission on Irrigation and Drainage. 1997.

10. The Economist online. The dirty, clean Czech Republic. Energy. 2011.

11. Santamouris M, Asimakopoulos D. Passive Cooling of Buildings. London; 1996:1.

12. Dimoudi A, Nikolopoulou M. Vegetation in the urban environment: Microclimatic analysis and benefits. Energy Build. 2003;35(1):69-76.

13. Mahmoud AHA. An analysis of bioclimatic zones and implications for design of outdoor built environments in Egypt. Build Environ. 2011;46(3):605-620.

14. Spangenberg J, Shinzato P, Johansson E, et al. Simulation of the influence of vegetation on microclimate and thermal comfort in the city of São Paulo. Rev. Soc. Bras. Arboriza Cão Urbana. 2008;3(2):1-19.

15. Wang W, Vinocur B, Altman A. Plant responses to drought, salinity and extreme temperatures: Towards genetic engineering for stress tolerance. Planta. 2003;218(1):1-14.

16. U.S. Fish, Wildlife Service. National Wildlife Refuge System: Biological Integrity, Diversity, and Environmental Health. US Fish and Wildlife Service, Washington: DC; 2001.

17. U.S. National Park Service. 4 Natural Resource Management. NPS Management Policies. 2000.

18. Haehle RG, Brookwell J. Native Florida Plants: Low Maintenance Landscaping and Gardening. Taylor Trade Publishing; United States; 2004.

19. Hostetler ME, Klowden G, Miller SW, et al. Landscaping Backyards for Wildlife: Top Ten Tips for Success, UF/IFAS EDIS. 2003.

20. Scheiber S, Gilman E, Sandrock D, et al. Post establishment landscape performance of Florida native and exotic shrubs under irrigated and no irrigated conditions. Hort Technol. 2008;18:59-67.

21. Fiedler AK, Landis D. Attractiveness of Michigan native plants to arthropod natural enemies and herbivores. Environ Entomol. 2007;36(4):751-765. 
22. Fiedler AK, Landis D. Plant characteristics associated with natural enemy abundance at Michigan native plants. Environ Entomol. 2007;36(4):878-886.

23. Brzuszek RF, Harkess RL, Mulley SJ. Landscape architects' use of native plants in the Southeastern United States. Hort Technol. 2007;17(1):78-81.

24. Paine T, Hanlon C, Pittenger D, et al. Consequences of water and nitrogen management on growth and aesthetic quality of drought tolerant woody landscape plants. J Environ Hort. 1992;10(2):94-99.

25. Crewe K. Arizona native plants and the urban challenge. Landsc J. 2013;32(2):215-229.

26. Reid S, Oki L. Field trials identify more native plants suited to urban landscaping. California Agriculture. 2008;62(3):97-104.

27. Uren HV, Dzidic PL, Bishop BJ. Exploring social and cultural norms to promote ecologically sensitive residential garden design. Landsc Urban Plan. 2015;137:76-84.

28. Danihelka J, Chrtek J, Kaplan Z. Checklist of vascular plants of the Czech Republic. Preslia. 2012;84:647-811.

29. Grulich V. Red List of vascular plants of the Czech Republic: 3rd ed. Preslia. 2012;84:631-645.

30. Kučera J, Ván̆a J, Hradílek Z. Bryophyte flora of the Czech Republic: updated checklist and Red List and a brief analysis. Preslia. 2012;84(3):813-850.

31. Krahulec F. History of the studies on the flora and vegetation in the Czech Republic. Preslia. 2012;84:397-426.

32. Chytrý M. Vegetation of the Czech Republic: diversity, ecology, history and dynamics. Preslia. 2012;84:427-504.

33. Kaplan Z. Flora and phytogeography of the Czech Republic. Preslia. 2012;84:505-574.

34. Pyšek P, Chytrý M, Pergl J, et al. Plant invasions in the Czech Republic: current state, introduction dynamics, invasive species and invaded habitats. Preslia. 2012;84:575-62.

35. Liška J. Lichen flora of the Czech Republic. Preslia. 2012;84(3):851-862.

36. Danihelka J. Botanické součty, rozdíly a podíly/Botanical counts. Živa. 2013;61:69-72.

37. Tolasz R, Míková T, Valeriánová A, et al. Atlas podnebí Česka. Český hydrometeorologický ústav, Praha and Univerzita Palackého v Olomouci; Olomouc: 2007.

38. Scott NE, Davison AW. The distribution and ecology of coastal species on roadsides. Ecology of coastal vegetation. 1985;6(2):433-440.

39. Perkins D. Winter salt gritting of roads provides a habitat for a sea shore plant. 2003.
40. Wrobel M. Origin and spatial distribution of roadside vegetation within the forest and agricultural areas in Szczecin Lowland (West Poland). Pol J Ecol. 2006;54(1):137-144.

41. Pyšek P, Sádlo J, Mandák B. Catalogue of alien plants of the Czech Republic. Preslia. 2002;74:97-186.

42. Šerá B. Roadside greenery in the open landscape. Životné Prostredie. 2005;39:208-211

43. Šerá B. Road vegetation in Central Europe - an example from the Czech Republic. Biologia. 2008;63(6):1081-1084.

44. Potts LE, Roll MJ, Wallner SJ. Colorado native plant survey voices of the green industry. Native Plants J. 2002;3:121-125.

45. Kauth PJ, Perez HE. Industry survey of the native wildflower market in Florida. Hort Technol. 2011;21(6):779-788.

46. Neufeld C. Assessment of the native plant materials industry in western Canada and the northern United States - Results from the providers and users of native plant materials. Native Plant Society of Saskatchewan. Saskatoon, SK: 2010:96.

47. Tamimi LN. The use of Native Hawaiian Plants by Landscape Architects in Hawaii. Virginia Tech. 1996.

48. Hooper VH. Understanding Utah's Native Plant Market: Coordinating Public and Private Interest. Utah State University. 2003.

49. Ricordi AH, Kaufman AJ, Cox LJ, et al. Going native in Hawail opportunities and barriers for using native plant material by landscape architects. Landscape J. 2014;33(2):127-139.

50. Gagliardi JA, Brand MH. Connecticut nursery and landscape industry preferences for solutions to the sale and use of invasive plants. Hort Technol. 2007;17(1):39-45.

51. Yue C, Hurley TM, Anderson N. Do native and invasive labels affect consumer willingness to pay for plants? Evidence from experimental auctions. Agri Econ. 2011;42(2):195-205.

52. Woosaree J. Market assessment of the native plant industry in western Canada. Alberta Environ, Alberta Agricultural Food Rural Development. Alberta Research Council. 2000.

53. Meyer SE. Intermountain native plant growers association: A nonprofit trade organization promoting landscape use of native plants. NPJ. 2005;6(2):104-107.

54. Peppin DL, Fule PZ, Lynn JC, et al. Market perceptions and opportunities for native plant production on the Southern Colorado Plateau. Restor Ecol. 2010;18(S1):113-124. 